\title{
Numerical simulations of Gurenhekou Glacier on the Tibetan Plateau using a full-Stokes ice dynamical model
}

L. Zhao ${ }^{1}$, L. Tian $^{2,3}$, T. Zwinger ${ }^{1,4}$, R. Ding ${ }^{1}$, J. Zong ${ }^{2}$, Q. Ye ${ }^{2}$, and J. C. Moore ${ }^{1,5,6}$

${ }^{1}$ College of Global Change and Earth System Science, Beijing Normal University, China

${ }^{2}$ Key Laboratory of Tibetan Environment Changes and Land Surface Processes, Institute of Tibetan Plateau Research, Chinese Academy of Sciences, Beijing 100085, China

${ }^{3}$ State Key Laboratory of Cryosphere Sciences, Cold and Arid Regions Environmental and Engineering Research Institute, Chinese Academy of Sciences, Lanzhou 730000, China ${ }^{4}$ CSC-IT Center for Science Ltd., Espoo, Finland

${ }^{5}$ Arctic Centre, University of Lapland, P.O. Box 122, 96101 Rovaniemi, Finland

${ }^{6}$ Department of Earth Sciences, Uppsala University, Villavägen 16, 75236 Uppsala, Sweden

Received: 14 November 2012 - Accepted: 11 December 2012 - Published: 8 January 2013 Correspondence to: J. C. Moore (john.moore.bnu @gmail.com)

Published by Copernicus Publications on behalf of the European Geosciences Union.

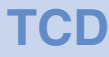

$7,145-173,2013$

Numerical simulation of a Tibetan Plateau glacier

L. Zhao et al.

Title Page

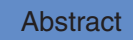

Introduction

Conclusions References

Tables Figures

14 $\rightarrow 1$

4

Back Close

Full Screen / Esc

Printer-friendly Version

Interactive Discussion 


\section{Abstract}

We investigate the impact of climate change on a small Tibetan glacier that is representative of the tens of thousands of mountain glaciers in the region. We apply a threedimensional, thermo-mechanically coupled full-Stokes model to Gurenhekou Glacier

5 located in the southern Tibetan Plateau. The steep and rugged geometry requires use of such a flow model to simulate the dynamical evolution of the glacier. We parameterize the temperature and mass balance using nearby automatic weather stations and an energy balance model for another glacier in the same mountain range. Summer air temperature increased at $0.02 \mathrm{Ka}^{-1}$ over the past $50 \mathrm{yr}$, and the glacier has 10 retreated at an average rate of $8.3 \mathrm{ma}^{-1}$. Prognostic simulations suggest an accelerated retreating rate up to $14 \mathrm{ma}^{-1}$ for the next $50 \mathrm{yr}$ under continued steady warming, which is consistent with observed increased retreat in the last decade. However, regional climate models suggest a marked increase in warming rate over Tibet during the 21 st century, and this rate causes about a $1 \%$ per year loss of glaciated area and 15 glacier volume. These changes imply that this small glacier will probably disappear in a century. Although Tibetan glaciers are not particularly sensitive to climate warming, the rather high warming rates predicted by regional climate models combined with the small sizes of most Tibetan glaciers suggest that significant numbers of glaciers will be lost in the region during the 21 st century.

\section{Introduction}

The Tibetan Plateau possesses tens of thousands of mountain glaciers and these glaciers provide water for many big rivers (e.g. Brahmaputra River, Ganges, Yellow River, Yangtze, Indus, Mekong) and have important effects on millions of people's life. Observation shows that many glaciers on the Tibetan Plateau have retreated rapidly in the past $30 \mathrm{yr}$ (Yao et al., 2007a; Xiao et al., 2007; Ding et al., 2006; Ye et al., 2006). Yao et al. $(2007 a, 2012)$ showed that there are important regional differences in the

\section{Numerical simulation of a Tibetan Plateau glacier}

L. Zhao et al.

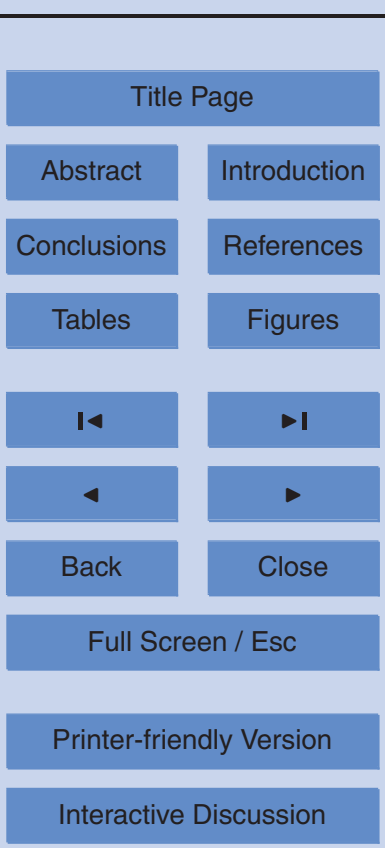


on-going response of Tibetan glaciers to climate change. The magnitude of glacier retreat increases from the continental interior to the margin of Tibetan Plateau, and reaches its maximum in the southern Tibetan Plateau and the Karakorum Mountains. Shi and Liu (2000) estimated future shrinkage of glaciers in China using an empiri5 cal relation between glacier and temperature rise since the Little Ice Age, finding that sub-continental glaciers would loose about $48 \%$ of their volume by 2100 under a $3^{\circ} \mathrm{C}$ temperature rise scenario. However, little work has been done modeling the future evolution of the glaciers when driven by climate model scenarios. Here we consider a small but representative glacier in the southern Tibetan Plateau and simulate its evolution in 10 the next $50 \mathrm{yr}$ under regional climate model forcing.

Few glaciers on Tibetan Plateau and surrounding regions have detailed geophysical observations, making modeling of their further evolution problematic. Glacier No. 1 has been modeled with the widely used Shallow Ice Approximation (SIA) ice dynamics models (Li H., 2010; Zhou et al., 2009). However, the steep and rough geometry combined with significant aspect ratio makes such SIA models theoretically unsuitable (e.g. Blatter et al., 2010, 2011; Greve and Blatter, 2009; Le Meur et al., 2004). In defense of such approaches it may be argued that on shorter timescale surface mass balance plays a much greater role in glacier evolution than flow dynamics since accumulation rates are relatively high while ice velocities are relatively low. A higher order flow dynamics model, however, is useful for looking at long term (multi-decadal) change and non-steady state conditions.

The open source numerical code Elmer/lce solves the complete three-dimensional, thermo-mechanically coupled ice dynamics equations (a so-called "full-Stokes" model, e.g. Zwinger and Moore, 2009; Zwinger et al., 2007). In addition to being suitable for mountain glacier dynamics, the model requires very few input data, essentially the bed and surface geometry and estimates of the basal heat flux, surface mass balance and temperature. In this article, the model is applied to Gurenhekou glacier $\left(90^{\circ} 28^{\prime} \mathrm{E}\right.$, $30^{\circ} 11^{\prime} \mathrm{N}$ ) which is located in the southern Tibetan Plateau, to simulate the ice dynamics in the present day and predict the dynamical evolution of this glacier in the next five

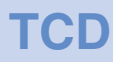

$7,145-173,2013$

\section{Numerical simulation of a Tibetan Plateau glacier}

L. Zhao et al.

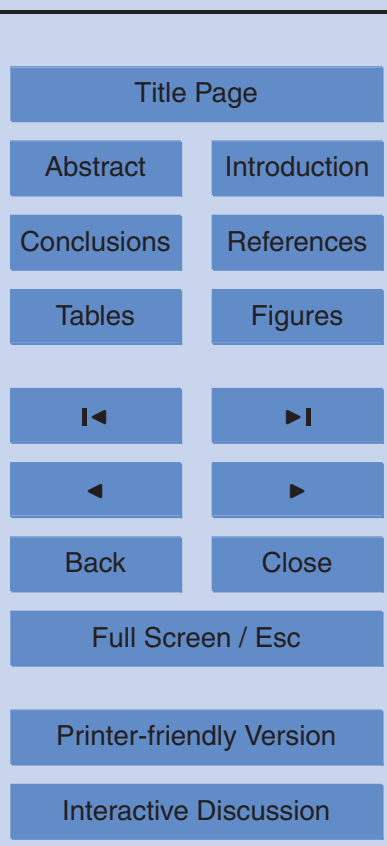


decades. To the best of our knowledge, this is the first use of a full-Stokes model to a glacier on Tibetan Plateau.

\subsection{Gurenhekou glacier}

Gurenhekou glacier is a small cold alpine-type valley glacier in the southeast part of 5 Nyainqentanglha Range in the central part of the southern Tibetan Plateau (Fig. 1). The region is of special interest for glacio-climatological research as it is influenced by both the continental climate of Central Asia and the Indian monsoon system, and is situated at the transition zone between temperate and sub-continental glaciers. The glacier is strikingly regular in shape, with an area of $1.40 \mathrm{~km}^{2}$ and a length of $2.9 \mathrm{~km}$ 10 (Fig. 2). The elevation of Gurenhekou glacier is about $5500 \sim 6000 \mathrm{~m}$ a.s.l. (Pu et al., 2006; Ma et al., 2007). The glacier is smooth and flat at the surface, but steep at the tongue and the mountain ridge at the sides of the glacier. Gurenhekou glacier is a summer-accumulation type of glacier, like most of glaciers on the Tibetan Plateau (Shi, Y., 2000; Fujita et al., 2000; Ageta et al., 1992).

15 Ground penetrating radar (GPR) and differential GPS measurements were taken in the years 2007, 2009 and 2011 (Ma et al., 2008, see Fig 2.). The surface elevation was measured along all the tracks in Fig. 2, and bed elevation only along the tracks " 2 2009", "3-2009", "1-2007", and "2-2007". Elevations above $5860 \mathrm{~m}$ were not surveyed due to terrain hazards, but ice thickness appears to be rather thin in those regions. The maximum thickness observed was $140 \mathrm{~m}$ along a transverse line and about 550 meters away from the head of this glacier.

\section{Surface temperature and surface mass balance on the glacier}

On decadal time scales, regional climate has strong control on glacier's surface temperature and surface mass balance (SMB), which in combination are the main driving force of the glacier dynamics and important boundary conditions to the full-Stokes

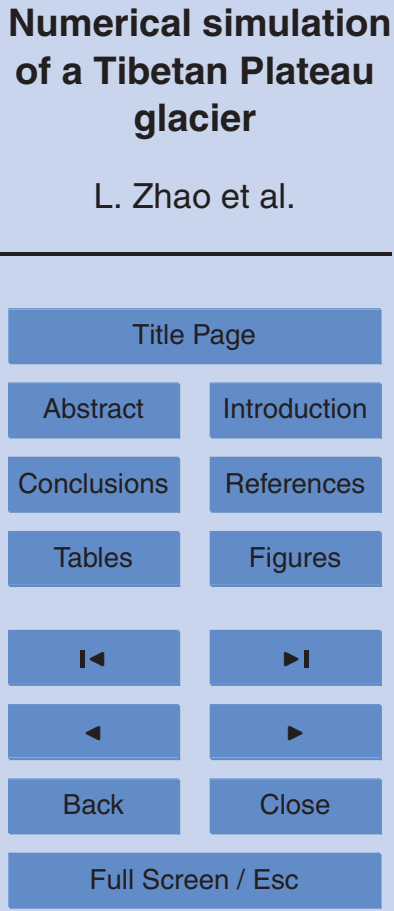

Printer-friendly Version

Interactive Discussion 
model. Therefore, correctly prescribing these two input fields is vital for accurate simulations and predictions of the present day and the future.

\subsection{Model setup}

We constructed surface and bedrock digital elevation model (DEM) for the year 2007.

5 Surface temperature was estimated by using the annual mean air temperature and lapse rates from 9 automatic weather stations (AWS) set up at a southern slope of Nyainqentanglha Range (Xie et al., 2010). A temperature inversion exists below elevations of $4950 \mathrm{~m}$, so we confine our data to 4 AWS above $4950 \mathrm{~m}$ to estimate the surface temperature as a function of elevation $(z)$

${ }_{10} T(z)=273.15+37.17-0.0075 z$

where the temperature $T$ is in units of Kelvin, $z$ denotes the elevation, and the lapse rate is $-0.0075 \mathrm{Km}^{-1}$. This regression neglects the temperature offset due to the presence of the glacier influencing local climate that may range from $0.2^{\circ} \mathrm{C}$ to $3.5^{\circ} \mathrm{C}(\mathrm{Shi}, 2000)$.

15 However, since the glacier is relatively small, and the ice free slopes are extensive (Figs. 1, 2), we neglect this effect. Since the glacier is below melting point throughout (see the diagnostic model, below), this offset would make little difference to the simulations in any event. Geothermal heat flux is approximated by using a measured temperature profile in an ice-core borehole of Naimonanyi Glacier on the southwestern 20 Tibetan Plateau (Yao et al., 2007b) and taken as $78.6 \mathrm{~mW} \mathrm{~m}^{-2}$.

\subsection{Surface mass balance}

Little information of surface mass balance is available for Gurenhekou glacier, due to the harsh climatic conditions and high altitude. By comparing the surface elevation along the central longitudinal profiles measured in 2007 and 2011 (Fig. 2), annual averaged rate of surface elevation change is obtained in the lower part of glacier (Fig. 3). In addition, mass balance during the period 2004-2010 was measured (Yao et al., 2012)

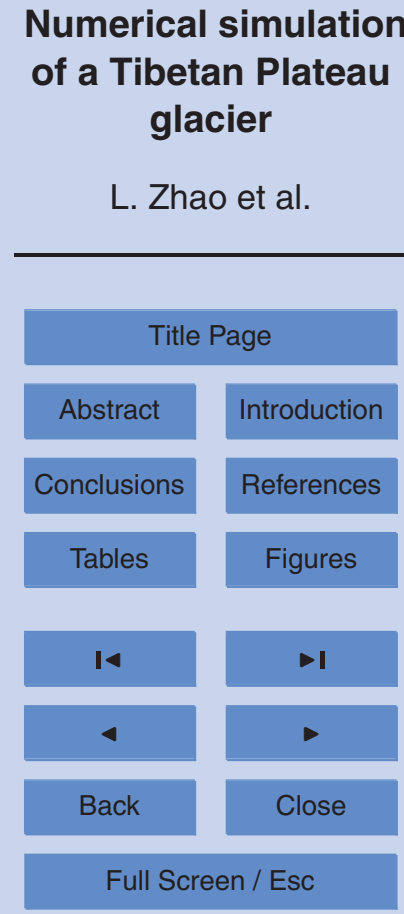

Printer-friendly Version

Interactive Discussion 
at 12 stakes on the glacier. Since the observations are over a relatively short period, we have to also rely on modeled surface mass balance. Caidong and Sorteberg (2010) used an energy balance model to simulate the mass balance of Xibu glacier $\left(90^{\circ} 36^{\prime} \mathrm{E}\right.$, $30^{\circ} 23^{\prime} \mathrm{N}$ ), which is a large glacier ( $12.7 \mathrm{~km}$ long) in the central part of Nyainqentan5 glha Range and $25 \mathrm{~km}$ northeast of Gurenhekou glacier. Their model produces three distinct mass balance regions as a function of altitude. It is reasonable to suppose that Gurenhekou glacier exhibits a similar mass balance profile, and we prescribe a mass balance gradient and SMB for each of these three regions. We can test this hypothesis using the observed change of the glacier surface elevation and the stake mass balance 10 measurements (Fig. 3).

The vertical mass balance gradient $(\beta)$ we use for Gurenhekou glacier is a function of altitude $(z)$ and equilibrium line altitude (ELA)

$\beta= \begin{cases}\beta_{1}=6 \times 10^{-4}, & \mathrm{ELA}+170<z<6100 \\ \beta_{2}=0.013, & \mathrm{ELA}-40<z<\mathrm{ELA}+170, \\ \beta_{3}=5 \times 10^{-3}, & 5400<z<\mathrm{ELA}-40\end{cases}$

and similarly the annual surface mass balance is

$\operatorname{SMB}(z)= \begin{cases}170 \beta_{2}+\beta_{1}(z-\mathrm{ELA}-170), & \mathrm{ELA}+170<z<6100 \\ \beta_{2}(z-\mathrm{ELA}), & \mathrm{ELA}-40 \leq z \leq \mathrm{ELA}+170 . \\ -40 \beta_{2}-\beta_{3}(\mathrm{ELA}-40-z), & 5400<z<\mathrm{ELA}-40\end{cases}$

The unit of SMB and $\beta_{i}(i=1,2,3)$ here is $\mathrm{ma}^{-1}$ (ice equivalent) and $\mathrm{a}^{-1}$, respectively.

The ELA of Gurenhekou glacier in the year 2008 is about $5800 \mathrm{~m}$ (Yao et al., 2012). Using Eq. (2) and (3) with an ELA $=5800 \mathrm{~m}$ is consistent with the rate of surface change observed during $2007 \sim 2011$ and the stake measurements during $2004 \sim 2010$ (Fig. 3).

Since the glacier is a summer accumulation type, the ELA is essentially determined only by the summer (JJA) climate. We can estimate the dependence of ELA on climate 150
$7,145-173,2013$

\section{Numerical simulation of a Tibetan Plateau glacier}

L. Zhao et al.

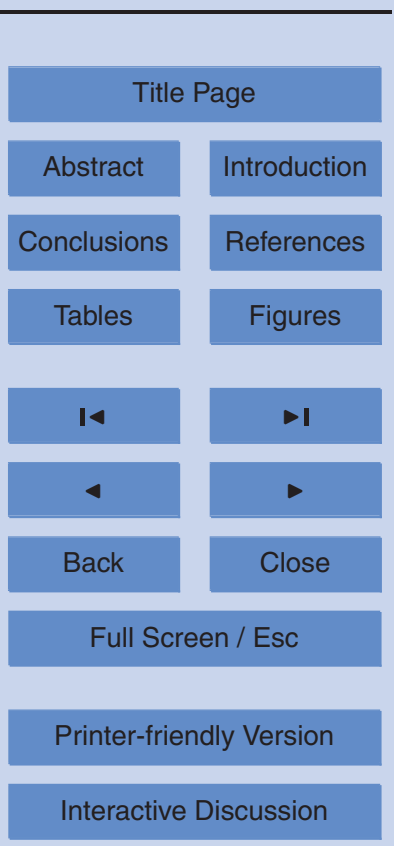

Interactive Discussion 
using the six balance years during $2004 \sim 2010$ (Yao et al., 2012) and observed JJAtemperature and JJA-precipitation at Lhasa station during $2005 \sim 2010$. We find that a $1 \mathrm{~K}$ air temperature rise results in a shift of ELA by $79 \pm 30 \mathrm{~m}$ on Gurenhekou glacier. There is no statistically significant dependence of ELA on JJA-precipitation. Hence,
$E L A_{(\mathrm{k})}=5800+79 \Delta T_{(\mathrm{k})}$,

where $\Delta T$ is the net change of JJA-temperature between 2008 and the $k$ th year and $79 \mathrm{~m} \mathrm{~K}^{-1}$ is the sensitivity of ELA to temperature change.

\section{Numerical model}

\subsection{Geometry set-up and meshing}

We constructed a digital elevation model (DEM) of the surface and bedrock by interpolation of the GPS and radar profiles (Fig. 2). Both the bedrock and surface profiles were smoothed and extended to the boundary defined from satellite images. Using the surface and bedrock DEM and the boundary shape, the three-dimensional geometry of Gurenhekou glacier was built by extruding the two-dimensional footprint from the bedrock to the surface containing 15 terrain-following layers of varying thickness (Fig. 4). We applied a refinement of layer thickness towards the bedrock to capture the highest deformation rates better. Additionally, a vertically section along the center line of the glacier was included for post processing reasons. The three-dimensional mesh main is decomposed into 6 parts for parallel computation. A diagnostic (steady state with fixed geometry) run only required $20 \mathrm{~min}$, and the $50 \mathrm{yr}$ prognostic run completed within $17 \mathrm{~h}$ on a workstation.

\section{TCD}

$7,145-173,2013$

Numerical simulation of a Tibetan Plateau glacier

L. Zhao et al.

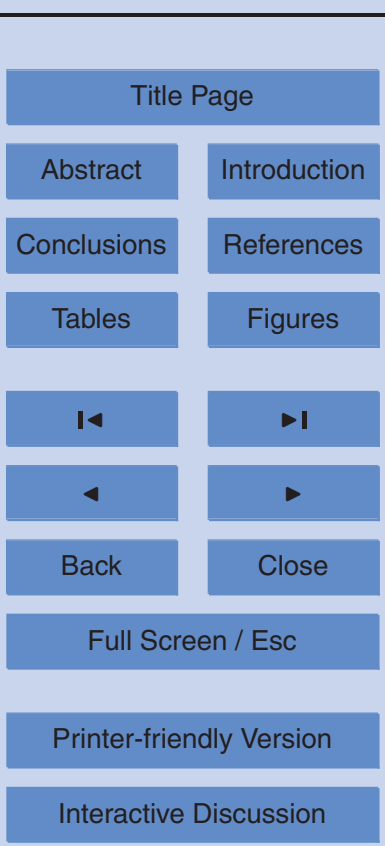




\subsection{Governing equations and boundary conditions}

A three-dimensional, thermo-mechanically coupled full-Stokes model was employed to model the glacier dynamics. Elmer/lce uses the Finite Element Method (FEM) to solve the partial differential equations. The full-Stokes model consists of a momentum 5 conservation equation, a mass conservation equation for an incompressible fluid and a heat transfer equation for the temperature:

$\nabla \cdot \boldsymbol{\tau}-\nabla p=\rho \boldsymbol{g}$

$\operatorname{div} \boldsymbol{u}=0$

$\rho c\left(\frac{\partial T}{\partial t}+(\boldsymbol{u} \cdot \nabla) T\right)=\operatorname{div}(k \nabla T)+\sigma$

where $\boldsymbol{u}=\left(u_{x}, u_{y}, u_{z}\right)$ denotes the ice flow velocity, $T$ is the temperature, $p$ is the pressure, and $g$ is the gravity acceleration. Ice density $\rho$ is assumed to be constant $910 \mathrm{~kg} \mathrm{~m}^{-3}$ due to the incompressibility condition. The deviatoric stress tensor, $\boldsymbol{\tau}$, is related to strain rate tensor, $\varepsilon=\left(\nabla \boldsymbol{u}+\nabla \boldsymbol{u}^{T}\right) / 2$, by the inverse form of Glen's Law (Cuffey and Paterson, 2010):

$\boldsymbol{\tau}=A(T)^{-1 / 3} \varepsilon_{\mathrm{E}}^{-2 / 3} \varepsilon$,

where $\varepsilon_{\mathrm{E}}=\sqrt{\frac{1}{2} \operatorname{tr}\left(\varepsilon^{2}\right)}$ is the effective strain tensor. The rate factor $A(T)$ is described by the Arrhenius law and the enhancement factor $E$ is taken as 1 . The heat capacity $c$ and the heat conductivity $k$ are functions of temperature

$c(T)=146.3+7.253 T, \quad k(T)=9.828 \exp \left(-5.7 \times 10^{-3} T\right)$

where the temperature is in Kelvin. Due to the relatively low strain-rates and stresses, we neglect the internal heat source $\sigma$ caused by strain heating.

Given the geothermal heat flux and surface temperatures of the glacier, we expect that the glacier is below melting point throughout the whole domain (this is supported

Numerical simulation of a Tibetan Plateau glacier

L. Zhao et al.

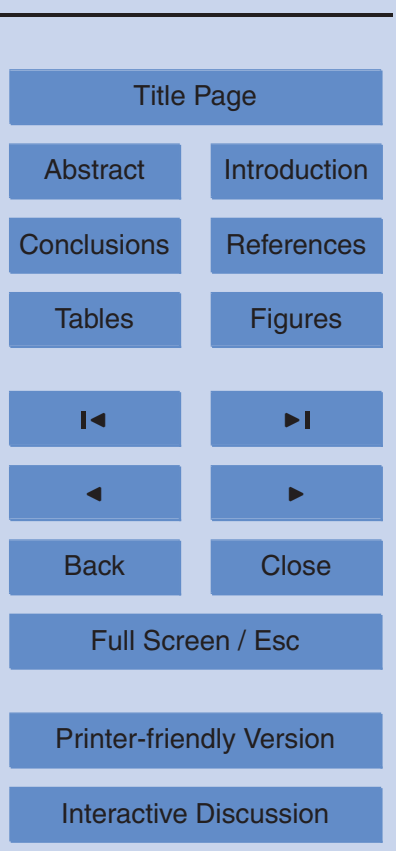

Interactive Discussion 
by the simulations below). Hence, we prescribe a no-slip boundary condition for velocity at the bedrock. At the surface of the glacier, the atmospheric pressure and wind stress exerted against the upper interface is neglected, which implies the deviatoric stress vector on the tangential plane of the surface vanishes, i.e.

$\left.{ }_{5} \tau \cdot \boldsymbol{n}\right|_{\text {surface }}=0$

where $\boldsymbol{n}$ is the unit normal vector of the surface.

The temperature at the glacier surface is taken as a function of elevation, see Eq. (1). At the bedrock, a Neumann boundary condition for the temperature is set:

$\kappa(T) \frac{\partial T}{\partial n}=q_{\mathrm{geo}}$

where the geothermal heat flux $q_{\text {geo }}$ is taken as $78.6 \mathrm{mWm}^{-2}$, as described earlier.

For the prognostic run, the kinematic boundary condition is applied at the surface since the surface elevation change with time,

$\frac{\partial h}{\partial t}+u_{x} \frac{\partial h}{\partial x}+u_{y} \frac{\partial h}{\partial y}-u_{z}=\mathrm{SMB}$

where $h$ is the surface elevation, and the surface mass balance SMB is estimated 15 by using Eqs. (2-3). The full-Stokes model is solved by using an open source FEM package Elmer/lce (http://elmerice.elmerfem.org).

\subsection{Model experiments}

We perform 3 separate simulations. The first is diagnostic simulation, i.e. assuming steady state with constant surface elevation which then defines a mass balance pattern over the glacier that is constant over time. We also perform 2 prognostic simulations with differing 21 st century temperature increases to produce mass balance on the glacier as a function of elevation and time. To produce estimates of warming rate
$7,145-173,2013$

\section{Numerical simulation of a Tibetan Plateau glacier}

L. Zhao et al.

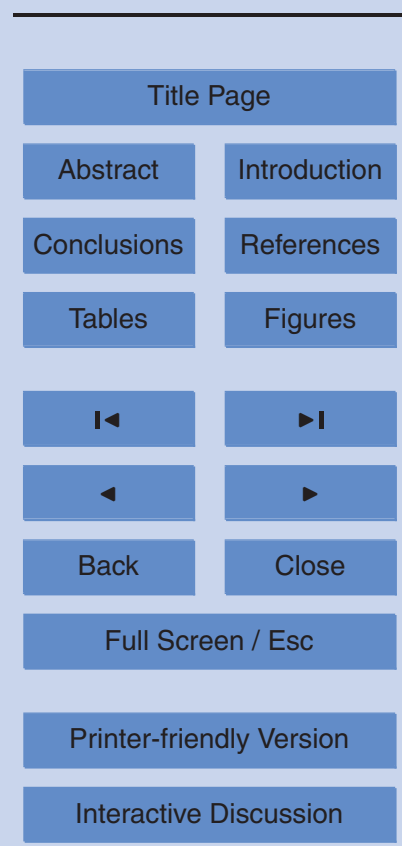


representative of the later half of the 20th century and the first half of this century, we use results from the Regional Climate Model Version 3.0 (RegCM3). The horizontal grid spacing of RegCM3 is $25 \mathrm{~km}$, and the model domain covers all of China and surrounding East Asia areas (Gao et al., 2012). RegCM3 reproduces the observed spatial 5 structure of surface air temperature and precipitation well.

Since the glacier is a summer accumulation type, conditions in June, July and August are far more important than the rest of the year. Figure 5 shows summer annual surface temperature evolution from 1951 to 2100 for the nine $25 \times 25 \mathrm{~km}$ grid boxes centered on the cell containing Gurenhekou glacier. Since we are interested in climatic impacts 10 rather than inter-annual variability in ELA caused by factors such as monsoon intensity etc. we focus on the smoothed response to temperature rises. Figure 5 shows that two simple linear rates $(\dot{T})$ of temperature rise fit both, the past simulated temperature history, and the simulated future temperature rise well. The historical simulation rate for the period 1955 to 2005 is $2{ }^{\circ} \mathrm{C}$ per century. This is also the observed temperature rise rate at Lhasa station (the station was established in 1955), hence we have confidence that the regional model reproduces observed temperature trends well in this area, and that this rate represents the on-going situation on the glacier. The second prognostic simulation uses a rate of $5^{\circ} \mathrm{C}$ per century for warming which is the slope of the RegCM3 result for the period $2005-2100$.

\subsubsection{Diagnostic simulation}

The initial surface DEM was built for the year 2007. The surface was kept constant at the 2007 geometry. The thermo-mechanically coupled model then produces a socalled "diagnostic" simulation for this geometry by using a fixed point iteration scheme. Figure 6 shows the simulated surface velocity. The maximum speed found is $1.92 \mathrm{ma}^{-1}$ 25 around the middle part of the glacier. The surface velocity in the southern terminus is about $0.4 \mathrm{ma}^{-1}$ due to the steep surface slope there. The temperature distribution at the bedrock and along the center line in Fig. 7 shows that the whole glacier is below pressure melting point. The highest temperature is about $-1.6^{\circ} \mathrm{C}$, hence justifying the

7, 145-173, 2013

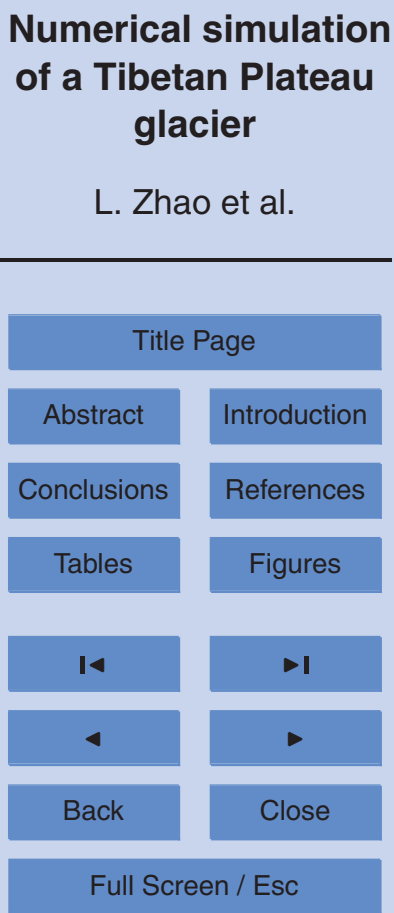

Printer-friendly Version

Interactive Discussion 
no basal sliding condition we imposed in the model setup. We also performed a "surface relaxation" experiment (Zwinger and Moore, 2009) to determine if parts of the glacier exhibit unrealistic surface velocities that are likely caused by errors in the surface or bedrock DEMs. We find that this procedure did not detect systematic errors in the 5 DEMs we used.

\subsubsection{Prognostic simulations with $\dot{T}=0.02 \& \dot{T}=0.05$}

The dynamical evolution of the glacier is simulated by so-called "prognostic" simulations. The steady state solution from the diagnostic run was taken as the starting point (initial condition) for the prognostic simulation from the year 2008 to 2057. The 10 surface mass balance was calculated by using (2) and (3) for the five decades. The thermo-mechanically coupled full-Stokes model and the kinematic boundary condition (12) were solved at each time step. Consequently, the surface DEM evolved every year due to ice movement and surface mass balance, and the resulting change of surface elevation and ELA then changed the surface mass balance. The surface elevation change from 2008 to 2057 is shown in Fig. 8. The termini in the year 2007, 2032 and 2057 are compared in Fig. 9.

In the first 25-yr period 2008-2032, the terminus of glacier in the northeast retreats more intensively than that in the southwest due to thinner ice there. The maximal retreat rate is about $13 \mathrm{ma}^{-1}$ in the northeast of the tongue and $4.6 \mathrm{ma}^{-1}$ in the southwest for 20 the period 2008-2032. There is no noticeable difference in both retreat rate and percentage of area loss for the period 2008-2032 between prognostic simulations using temperature rise rate of $\dot{T}=0.02 \mathrm{Ka}^{-1}$ and using $\dot{T}=0.05 \mathrm{Ka}^{-1}$ (see Table 1).

Using topographic maps and aerial photos, the annual average retreat rate of this glacier was about $7.0 \mathrm{ma}^{-1}$ from the last of Little Ice Age to the 1970 s and $8.3 \mathrm{ma}^{-1}$ 25 during 1974-2004. In-situ observations showed that the glacier retreated at $9.5 \mathrm{ma}^{-1}$ from 2004 to 2005 and $17.0 \mathrm{ma}^{-1}$ from 2005 to 2006 (Pu et al., 2006). Hence the modeled retreat rate is consistent with the trend over the last decade. The similarity of retreat rate under the $2^{\circ} \mathrm{C}$ and $5^{\circ} \mathrm{C}$ per century scenarios shows that the observed rapid

\section{TCD}

$7,145-173,2013$

\section{Numerical simulation of a Tibetan Plateau glacier}

L. Zhao et al.

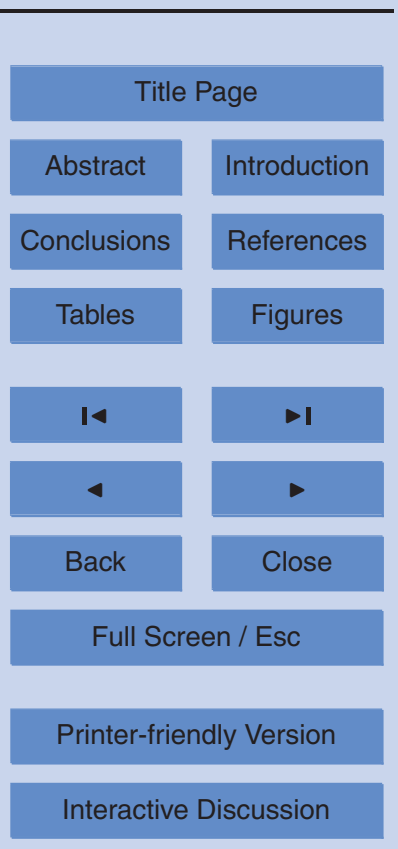


acceleration between 2004 and 2006 is likely due to inter annual climate variability and stochastic variability in local ice thickness rather than to a change in summer warming rate. The modeled retreat rate is also consistent with the retreat rates of about $10 \mathrm{ma}^{-1}$ for five glaciers in Nyainqentanglha range from 1976 to 2009 (Bolch et al., 2010).

The annual average area reduction rate during 2008-2032 is about $-0.96 \%$ with $\dot{T}=$ $0.02 \mathrm{Ka}^{-1}$ and $-1.08 \%$ with $\dot{T}=0.05 \mathrm{Ka}^{-1}$. These estimates are much greater than annual area change observed in southeast Nyainqentanglha Range during the period 1980-2001 of $-0.17 \%$ per year (Yao et. al, 2012) and during 1976-2001 of $-0.22 \%$ per year (Bolch et al, 2010) based on remote sensing images and maps, but similar 10 to the estimated $-0.7 \%$ per year from Frauenfelder and Kääb (2009) over a similar period. We discuss these differences further in Sect. 4.

In the second $25 \mathrm{yr}$ period 2033-2057, the retreat rates of glacier terminus using $\dot{T}=0.02 \mathrm{Ka}^{-1}$ and $\dot{T}=0.05 \mathrm{Ka}^{-1}$ are also similar, with the maximum of about $14.6 \mathrm{ma}^{-1}$. However, there is obviously more area reduction (see Table 1) from prog15 nostic simulations using $\dot{T}=0.05 \mathrm{Ka}^{-1}$ than that using $\dot{T}=0.02 \mathrm{Ka}^{-1}$. The largest differences are in the upper glacier, since there the glacier is very thin and surface lowering exposes bedrock (see Fig. 8). The annual average area decreasing rate during 2033-2057 is $-0.44 \%$ with $\dot{T}=0.02 \mathrm{Ka}^{-1}$ and $-0.74 \%$ with $\dot{T}=0.05 \mathrm{Ka}^{-1}$.

In either case using $\dot{T}=0.02 \mathrm{Ka}^{-1}$ or $\dot{T}=0.05 \mathrm{Ka}^{-1}$, the area loss rate is slower

in the second $25 \mathrm{yr}$ than the first $25 \mathrm{yr}$, however, the volume shrinkage rate is almost the same during the five decades. Faster increasing temperature rate causes greater surface thinning (Fig. 8) and more intensive volume loss (see Table 1).

The surface velocity pattern of the ice flow looks similar in each year, but the magnitude of surface velocity shows a decreasing trend. The maximum value of sur25 face velocity decreases from $1.92 \mathrm{ma}^{-1}$ in the year 2007 (Fig. 6) to $0.96 \mathrm{ma}^{-1}$ with $\dot{T}=0.02 \mathrm{Ka}^{-1}$ and $0.32 \mathrm{ma}^{-1}$ with $\dot{T}=0.05 \mathrm{Ka}^{-1}$ in the year 2057 (Fig. 9). The decreasing trend is because the glacier thinning dominates ice flow speed despite the increasing steepness as the accumulation area builds up and the ablation area thins.

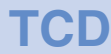

$7,145-173,2013$

\section{Numerical simulation of a Tibetan Plateau glacier}

L. Zhao et al.

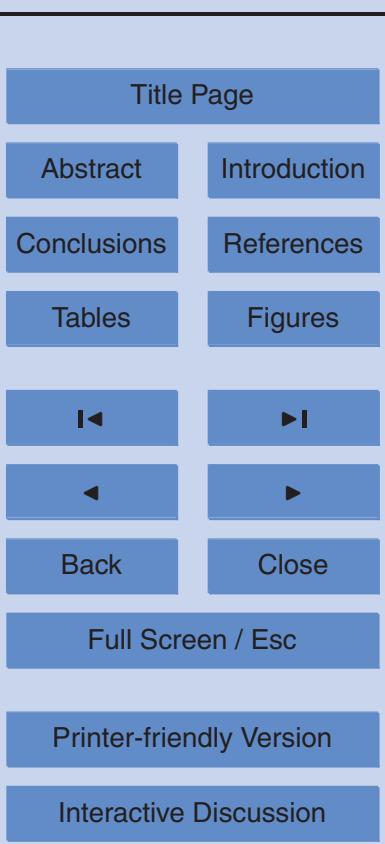



2057.

In these simulations we limited the maximal surface increase at any point on the glacier to $15 \mathrm{~m}$. We chose to do this because the valley glacier is unlikely to grow above

5 the level of the surrounding mountain ridge and side walls. If the glacier did grow the flow geometry would change dramatically as overflow out of the valley would occur (with no geomorphological evidence of it having done so), and also the new geometry would affect the snow accumulation pattern and effectively destroy the basic assumptions of the mass balance model. However we tested the impact of such a constraint on 10 ice elevation increase in the accumulation area on the net glacier area and volume change. We performed two prognostic simulations for $20 \mathrm{yr}$ using $\dot{T}=0.02 \mathrm{Ka}^{-1}$ : one as previously with maximal surface increase restricted by $15 \mathrm{~m}$, and the other with unrestricted elevation rise. The surface changes in two cases are shown in Fig. 10. Only a small fraction of glacier surface increases by more than $15 \mathrm{~m}$ in the unrestricted case.

15 The area loss is the same in both cases, at the rate of $-0.91 \%$ per year. The annual volume change rate is $-0.85 \%$ in the unrestricted case and $-0.89 \%$ in the restricted case. Therefore, we are confident that the maximal surface increase of $15 \mathrm{~m}$ will keep this glacier geometry realistic and will not introduce large differences in estimates of glacier change.

\section{Discussion and conclusion}

Prognostic simulations have been made for the period 2008-2057 using different temperature change rates, $\dot{T}=0.02 \mathrm{Ka}^{-1}$ and $\dot{T}=0.05 \mathrm{Ka}^{-1}$, to produce mass balance on the glacier as a function of elevation and time. For the first $25 \mathrm{yr}$ period 20082032 , the computed maximal retreat rate for Gurenhekou glacier is about $13 \mathrm{ma}^{-1}$, and

25 the annual average area reduction rate is about $-0.96 \%$ with $\dot{T}=0.02 \mathrm{Ka}^{-1}$. There is no noticeable difference in terminus retreat rate and area change rate between prognostic simulations using $\dot{T}=0.02 \mathrm{Ka}^{-1}$ and $\dot{T}=0.05 \mathrm{Ka}^{-1}$. For the second $25 \mathrm{yr}$

\section{Numerical simulation of a Tibetan Plateau glacier}

L. Zhao et al.

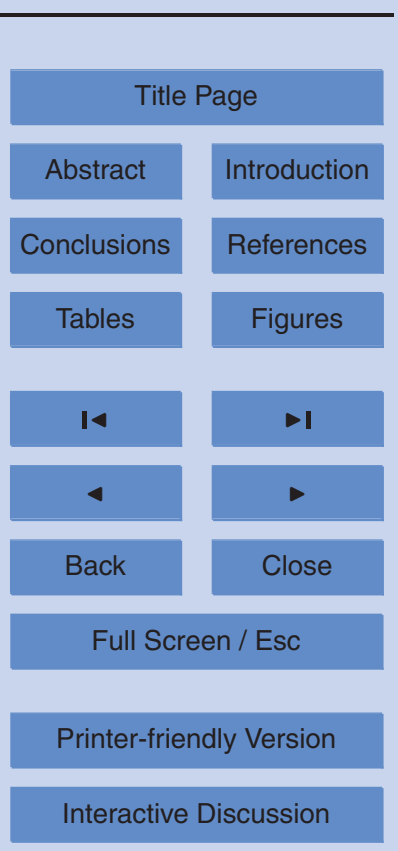

Interactive Discussion 
period 2033-2057, the computed maximal retreat rate for Gurenhekou glacier is about $14.6 \mathrm{ma}^{-1}$, and the annual average area loss rate is about $-0.44 \%$ with $\dot{T}=0.02 \mathrm{Ka}^{-1}$ and $-0.74 \%$ with $\dot{T}=0.05 \mathrm{Ka}^{-1}$. The modeled retreat rate is consistent with the trend observed over the last decade.

5 In either scenario, $\dot{T}=0.02 \mathrm{Ka}^{-1}$ or $\dot{T}=0.05 \mathrm{Ka}^{-1}$, the area loss rate is much slower in the second $25 \mathrm{yr}$ than the first $25 \mathrm{yr}$, however, the rate of volume loss remains almost unchanged over the whole five decades. This is because for this uniform width glacier, the volume loss depends mostly on the surface mass balance. The function we specify for mass balance depends linearly on temperature which we increase at constant rate 10 over time in our scenarios. In contrast, the rate of area loss depends on the relative surface and bedrock slopes close to the terminus. The higher temperature rise rate $\dot{T}=0.05 \mathrm{Ka}^{-1}$ results in more surface thinning, and hence greater volume loss than the lower temperature rise rate.

The annual average volume change for the period $2008-2057$ is about $-1.03 \%$ using ${ }_{15} \dot{T}=0.02 \mathrm{Ka}^{-1}$ and $-1.46 \%$ using $\dot{T}=0.05 \mathrm{Ka}^{-1}$, respectively. These changes suggest that this glacier will probably disappear within a century. This glacier is typical in many respects of many small glaciers in the Nyainqentanglha region: in its size, elevation range, recent retreat rate and aspect. Bolch et al. (2010) report that only about 40 out of 960 glaciers in the Nyainqentanglha range are larger than $1 \mathrm{~km}^{2}$ in area, and they make up about $28 \%$ of the total glacier area. Hence if our results are representative then they suggest that $95 \%$ of glaciers in the range would disappear by 2100 . Bolch et al. (2010) estimated that areal loss rates were about $-0.25 \%$ per year over across the whole the Nyainqentanglha range for the period 1976-2001. This rate is significantly lower than some other studies in the region that report area loss rates of $-0.7 \%$ per year for southeast Nyainqentanglha range (Frauenfelder and Kääb, 2009). It is clear that some differences in remote sensing and mapping glacier areas result from inconsistencies in defining termini on debris-covered or seasonal snow obscured glaciers. Detailed analysis of five glaciers by Bolch et al. (2010) showed an increased rate between 2001

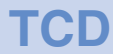

$7,145-173,2013$

\section{Numerical simulation of a Tibetan Plateau glacier}

L. Zhao et al.

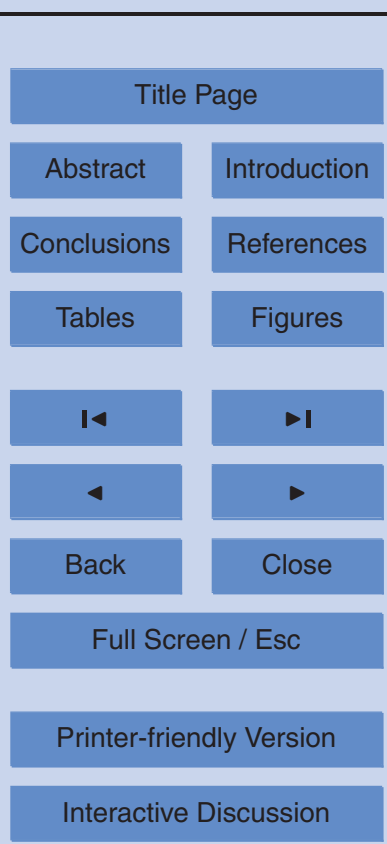


and 2009 of $-0.5 \%$ per year, but with large variations from -0.16 to $-0.84 \%$ per year. Hence it is not clear if Gurenhekou glacier is really representative in its area loss rate.

Reasons for differences in mass wastage estimates include varying climate across the mountain range (Shangguan et al., 2008), debris cover which provides insulating 5 cover on small scales but can cause accelerated mass loss on larger scales (e.g. Benn et al., 2012), and general stochastic variability between glacier responses to climate forcing. There is a difference in climate between the northeast and southwest sides of the Nyainqentanglha range (Shangguan et al., 2008), with the southeast side receiving more snow fall than the northwest side and also more direct radiation, at present 10 the two sides have similar average areal loss rates (Bolch et al., 2010; Shangguan et al., 2008). In future, since regional climate models suggest only modest increases in precipitation, but large temperature rises, it is likely that southerly facing glaciers will accelerate their mass loss. Furthermore using the past changes as guide to future change may not be reliable as decreases in surface albedo from deposition of anthropogenic pollutants is becoming more significant (Xu et al., 2009; Ramanathan and Carmichael, 2008). In the Nyainqentanglha range only about 29 glaciers have significant debris cover (Bolch et al., 2010), and recent observations of glacier thinning rates on the Tibet Plateau indicate similar rates for both clean and debris covered glaciers (Kääb et al., 2012; Gardelle et al., 2012). This can be explained by the spatially inhomogeneous ablation processes on debris covered glaciers (Gardelle et al., 2012; Benn et al., 2012) whereby the peak ablation occurs up-glacier of the tongue and is driven by rapid down-wasting associated with supraglacial melt ponds and thermokarst processes that effectively cut off the terminus from the dynamical ice flow. Over Tibet as a whole, total volume is likely dominated by ice in large glaciers. These glaciers, being thicker, will suffer proportionally less ice wastage per year and remain well past the end of this century.

\section{Numerical simulation of a Tibetan Plateau glacier}

L. Zhao et al.

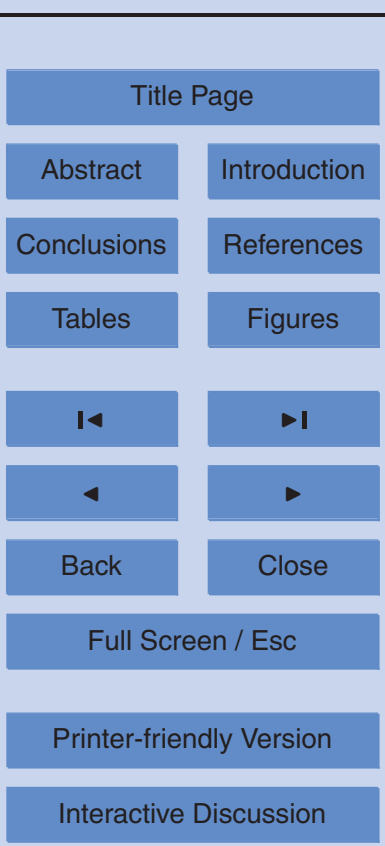


Acknowledgement. This study has been supported by National Key Science Program for Global Change Research (No. 2010CB950504), National Natural Science Foundation of China (No. 41076125). The authors thank the National Climate Center for providing the RegCM3 output data for this study.

\section{References}

Ageta, Y. and Kadota, T.: Predictions of changes of glacier mass balance in the Nepel Himalaya and Tibetan Plateau: a case study of air temperature increase for three glaciers, Ann. Glaciol., 16, 89-94, 1992.

Benn, D. I., Bolch, T., Hands, K., Gulley, J., Luckman, A., Nicholson, L. I., Quincey, D., Thompson, S., Toumi, R., and Wiseman, S.: Response of debris-covered glaciers in the Mount Everest region to recent warming and implications for outburst flood hazards, Earth-Sci. Rev., 114, 156-174, 2012.

Blatter, H., Greve, R., and Abe-ouchi, A.: A short history of the thermomechanical theory and modeling of glaciers and ice sheets, J. Glaciol., 56, 1087-1094, 2010.

15 Blatter, H., Greve, R., and Abe-Ouchi, A.: Present state and prospects of ice sheet and glacier modelling, Surv. Geophys., 32, 555-583, 2011.

Bolch, T., Yao, T., Kang, S., Buchroithner, M. F., Scherer, D., Maussion, F., Huintjes, E., and Schneider, C.: A glacier inventory for the western Nyainqentanglha Range and the Nam Co Basin, Tibet, and glacier changes 1976-2009, The Cryosphere, 4, 419-433, doi:10.5194/tc4-419-2010, 2010.

Caidong, C. and Sorteberg, A.: Modelled mass balance of Xibu glacier, Tibetan Plateau: sensitivity to climate change, J. Glaciol., 56, 235-248, 2010.

Cuffey, K. M. and Paterson, W. S. B.: The Physics of Glaciers, 4th edn., ButterworthHeinemann, Oxford, UK, 2010.

25 Ding, Y., Liu, S., Li, J., and Shangguan, D.: The retreat of glaciers in response to recent climate warming in western China, Ann. Glaciol., 43, 97-105, 2006.

Fujita, K., Ageta, Y., Pu, J., and Yao, T.: Mass balance of Xiao Dongkemadi glacier on the central Tibetan Plateau from 1989 to 1995, Ann. Glaciol., 31, 159-163, 2000.

Frauenfelder, R. and Kääb, A.: Glacier mapping from multi-temporal optical remote sensing data within the Brahmaputra river basin, Proc. 33rd int. Symposium on Remote Sensing of

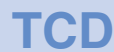

$7,145-173,2013$

\section{Numerical simulation of a Tibetan Plateau glacier}

L. Zhao et al.

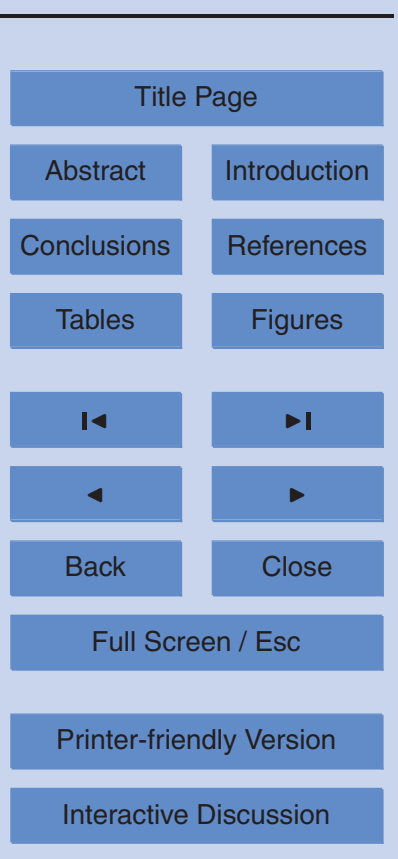

Interactive Discussion 
Environment, 4-8 May 2009, Stresa, Italy, Tucson, Arizona, InternationalCenter of Remote Sensing of Environment, Paper 299, 4 pp., 2009.

Gao, X. J., Shi Y., Zhang, D. F., and Giorgi, F.: Climate change in China in the 21st century as simulated by a high resolution regional climate model, Chinese Sci. Bull., 57, 1188-1195, 52010.

Gardelle, J., Berthier, E., and Arnaud, Y.: Slight mass gain of Karakoram glaciers in the early twenty-first century, Nat. Geosci., 5, 322-325, 2012.

Greve, R. and Blatter, H.: Dynamics of Ice Sheets and Glaciers, Springer, Berlin, Germany etc., 2009.

10 Kääb, A., Berthier, E., Nuth, C., Gardelle, J., and Arnaud, Y.: Contrasting patterns of early twenty-first-century glacier mass change in the Himalayas, Nature, 488, 495-498, 2012.

Le Meur, E., Gagliardini, O., Zwinger, T., and Ruokolainen, J.: Glacier flow modelling: a comparison of the Shallow Ice Approximation and the full-Stokes equation, C. R. Phys., 5, 709-722, 2004.

$\mathrm{Li}, \mathrm{H} .:$ Dynamic modeling study on mountain glaciers in China - take Urumqi Glacier No. 1 as an example, Ph.D. Thesis, State Key Laboratory of Cryosphere Sciences, Chinese Academy of Sciences, Lanzhou, 2010.

Ma, L., Tian, L., Yang, W., and Tang, W.: Measuring the depth of Gurenhekou Glacier in the south of the Tibetan Plateau using GPR and estimating its volume based on the outcomes,

20 J. Glaciol. Geocryol., 30, 783-788, 2008 (in Chinese with English abstract).

Pu, J., Yao, T., and Tian, L.: Change of the Gurenhekou Glacier in Yangbajain area, Nyainqentanglha Range, J. Glaciol. Geocryol., 28, 861-864, 2006 (in Chinese with English abstract).

Ramanathan, V. and Carmichael, G.: Global and regional climate changes due to black carbon, Nat. Geosci., 1, 221-227, 2008.

Shangguan, D., Liu, S., Ding, L., Zhang, S., Li, G., Zhang, Y., and Li, J.: Variation of glaciers in the western Nyainqentanglha Range of Tibetan Plateau during 1970-2000, J. Glaciol. Geocryol., 30, 204-210, 2008 (in Chinese with English abstract).

Shi, Y. and Liu, S.: Estimation on the response of glaciers in China to the global warming in the 21st century, Chinese Sci. Bull., 45, 668-672, 2000.

30 Shi, Y.: Glaciers and Their Environments in China - the Present, Past and Future, Science Press, Beijing, 2000 (in Chinese).

\section{Numerical simulation of a Tibetan Plateau glacier}

L. Zhao et al.

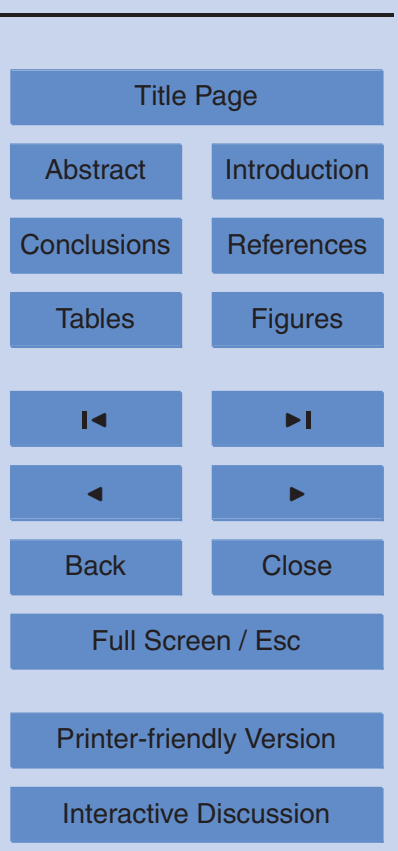


Xiao, C., Liu, S., Zhao, L., Wu, Q., Li, P., Liu, C., Zhang, Q., Ding, Y., Yao, T., Li, Z., and Pu, J.: Observed changes of cryosphere in China over the second half of the 20th century: an overview, Ann. Glaciol., 46, 382-390, 2007.

Xie, J., Liu, J., Du, M., and Wang, Z.: Altitudinal distribution of air temperature over a southern 5 slope of Nyainqentanglha Mountains, Tibetan Plateau, Sci. Geogr. Sinica, 30, 113-118, 2010 (in Chinese with English abstract).

Xu, B., Cao, J., Hansen, J., Yao, T., Joswia, D. R., Wang, N., Wu, G., Wang, M., Zhao, H., Yang, W., Liu, X., and He, J.: Black Soot and the Survival of Tibetan Glaciers, Proc. Natl. Acad. Sci. USA, 106, 22114-22118, 2009.

10 Yao, T., Pu, J., Lu, A., Wang, Y., and Yu, W.: Recent glacial retreat and its impact on hydrological processes on the Tibetan Plateau, China, and surrounding regions, Arct. Antarct. Alp. Res., 39, 642-650, 2007a.

Yao, T., Pu, J., Tian, L., Yang, W., Duan, K., and Ye, Q.: Recent rapid retreat of the Naimonanyi Glacier in southwestern Tibetan Plateau, J. Glaciol. Geocryol., 29, 503-508, 2007b (in Chinese with English abstract).

Yao, T., Thompson, L., Yang, W., Yu, W., Gao, Y., Guo, X., Yang, X., Zhao, H., Duan, K., Xu, B., $\mathrm{Pu}$, J., Lu, A., Qin, D. H., Xiang, Y., Kattel, D. B., and Joswiak, D.: Different glacier status with atmospheric circulations in Tibetan Plateau and surroundings, Nat. Clim. Change, 2, 663-667, doi:10.1038/nclimate1580, 2012.

20 Ye, Q., Kang, S., Chen, F., and Wang, J.: Monitoring glacier variations on Geladandong Mountian, central Tibetan Plateau, from 1969 to 2002 using remote-sensing and GIS technologies, J. Glaciol., 52, 537-545, 2006.

Zhou, Z., Li, Z., Li, H., and Jing, Z.: The flow velocity features and dynamic simulation of the Glacier No. 1 at the Headwaters of Urumqi River, Tianshan Mountains, J. Glaciol. Geocryol., 31, 42-69, 2009 (in Chinese with English abstract).

Zwinger, T., Greve, R., Gagliardini, O., Shiraiwa, T., and Lyly, M.: A full Stokes-flow thermomechanical model for firn and ice applied to the Gorshkov crater glacier, Kamchatka, Ann. Glaciol., 45, 29-37, 2007.

Zwinger, T. and Moore, J. C.: Diagnostic and prognostic simulations with a full Stokes model accounting for superimposed ice of Midtre Lovénbreen, Svalbard, The Cryosphere, 3, 217229, doi:10.5194/tc-3-217-2009, 2009.

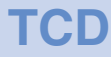

$7,145-173,2013$

\section{Numerical simulation of a Tibetan Plateau glacier}

L. Zhao et al.

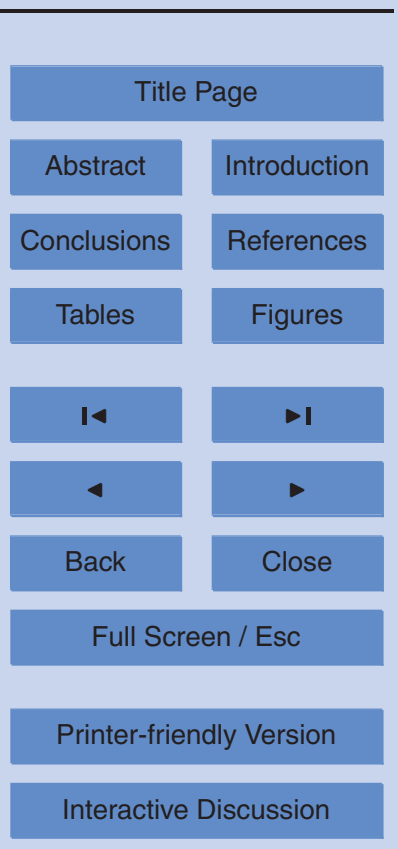




\section{TCD}

$7,145-173,2013$

Numerical simulation of a Tibetan Plateau glacier

L. Zhao et al.

Table 1. Annual area and volume percentage change during 2008-2057 from the prognostic simulations with $\dot{T}=0.02 \mathrm{Ka}^{-1}$ and $\dot{T}=0.05 \mathrm{Ka}^{-1}$.

\begin{tabular}{lcccc}
\hline Periods & \multicolumn{2}{c}{$\dot{T}=0.02 \mathrm{Ka}^{-1}$} & \multicolumn{2}{c}{$\dot{T}=0.05 \mathrm{Ka}^{-1}$} \\
& $\Delta \mathrm{A}$ & $\Delta \mathrm{V}$ & $\Delta \mathrm{A}$ & $\Delta \mathrm{V}$ \\
\hline $2008-2032$ & $-0.96 \%$ & $-0.99 \%$ & $-1.08 \%$ & $-1.33 \%$ \\
$2033-2057$ & $-0.44 \%$ & $-1.07 \%$ & $-0.74 \%$ & $-1.59 \%$ \\
$2008-2057$ & $-0.70 \%$ & $-1.03 \%$ & $-0.91 \%$ & $-1.46 \%$ \\
\hline
\end{tabular}

Title Page

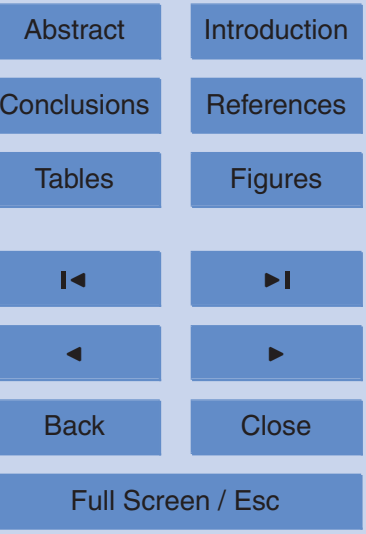

Printer-friendly Version

Interactive Discussion 


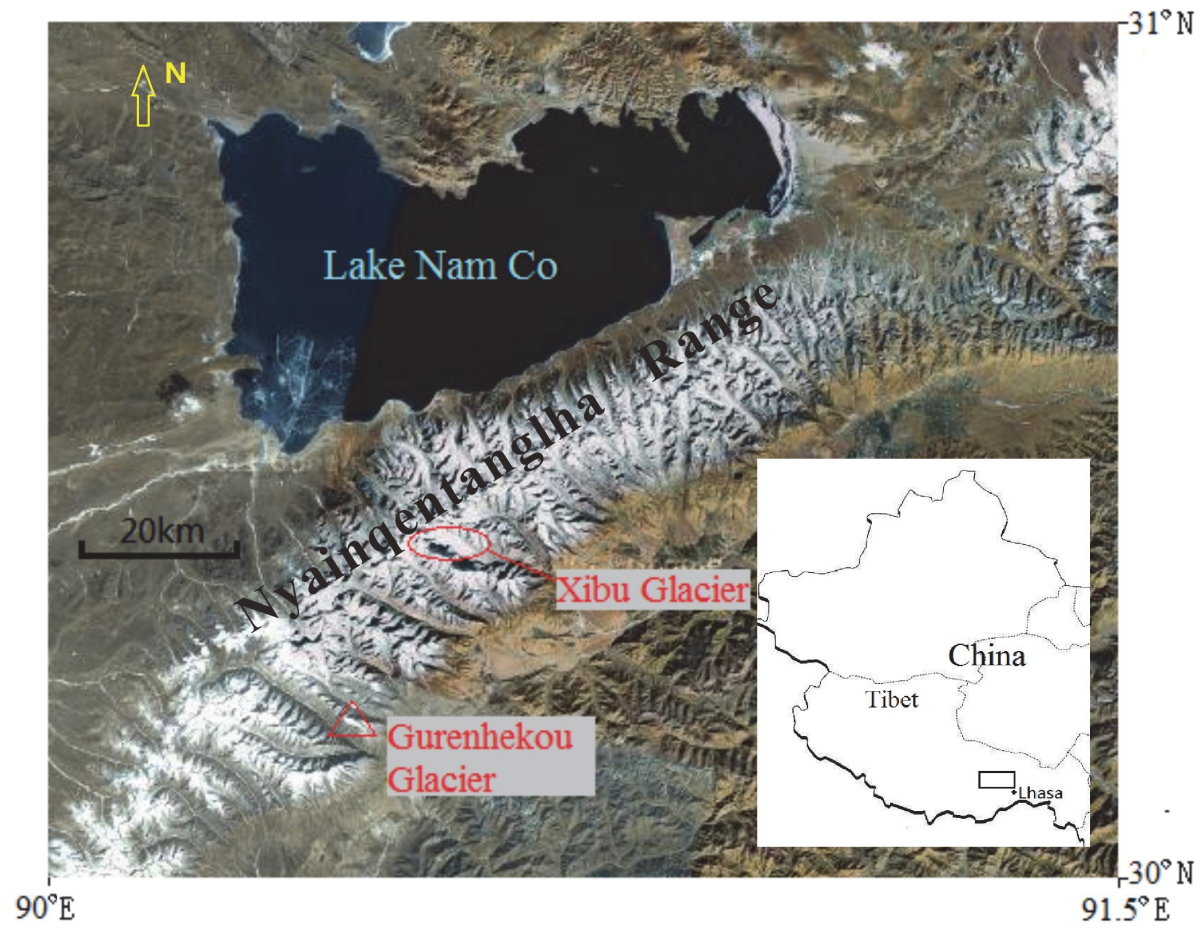

\section{TCD}

$7,145-173,2013$

\section{Numerical simulation of a Tibetan Plateau glacier}

L. Zhao et al.

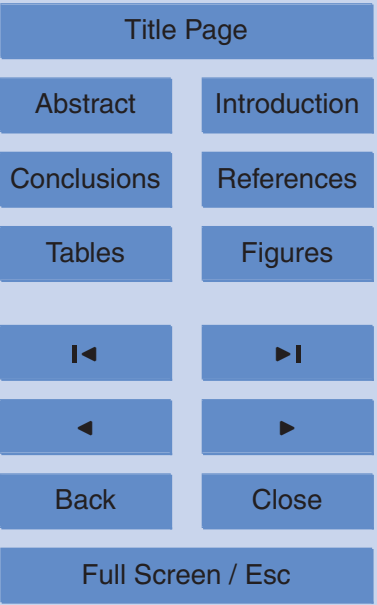

Fig. 1. The location of Nyainqentanglha Range, Lake Nam Co, Gurenhekou glacier and Xibu glacier. The box in the map of China indicates the location of study area in China.

Printer-friendly Version

Interactive Discussion

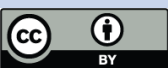




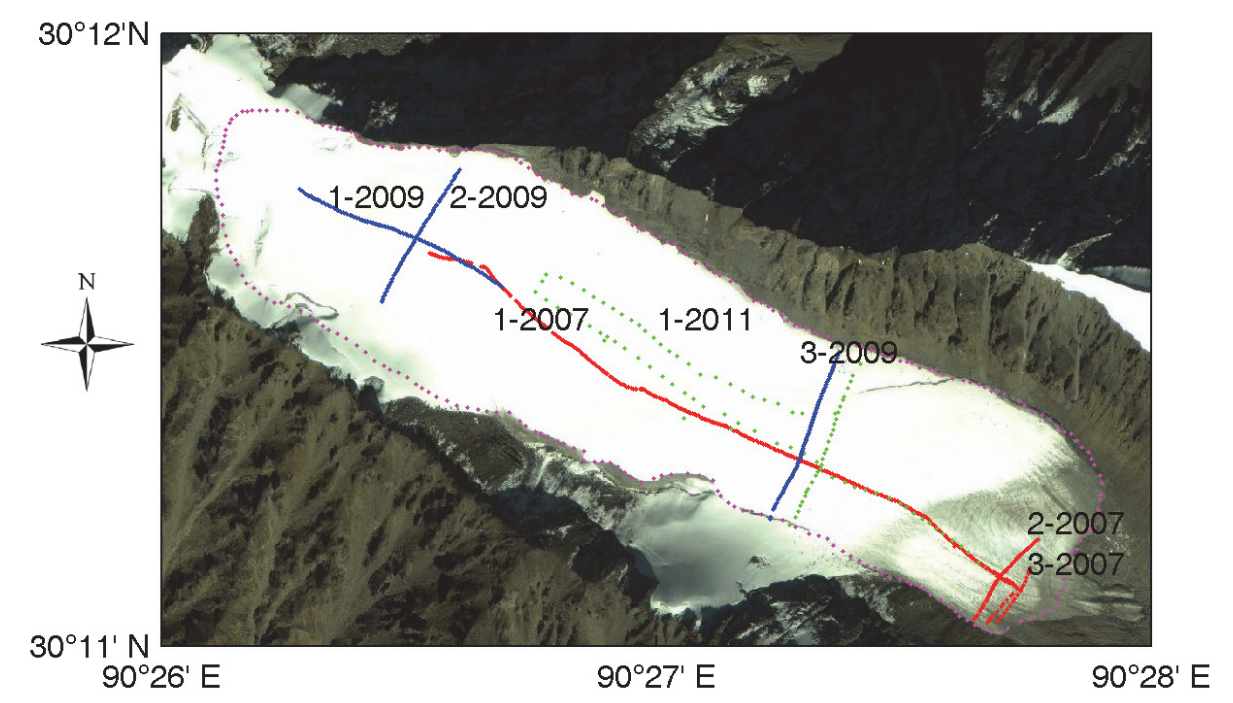

Fig. 2. The magenta curve is the boundary profile of Gurenhekou glacier. The boundary profile of the glacier is taken from satellite remote sensing image, and fits well with the real image of the glacier from Google maps. Seven tracks were measured in the years 2007, 2009 and 2011. Tracks in different years are denoted in different colors: red for 2007, blue for 2009, green for 2011. For instance, "1-2009" means the first track measured in the year 2009.

\section{TCD}

$7,145-173,2013$

\section{Numerical simulation of a Tibetan Plateau glacier}

L. Zhao et al.

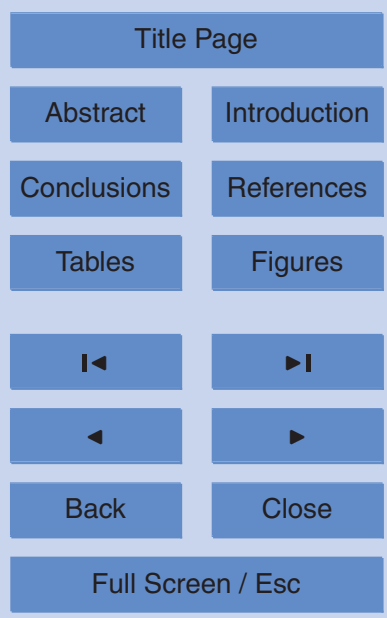

Printer-friendly Version

Interactive Discussion 


\section{TCD}

$7,145-173,2013$

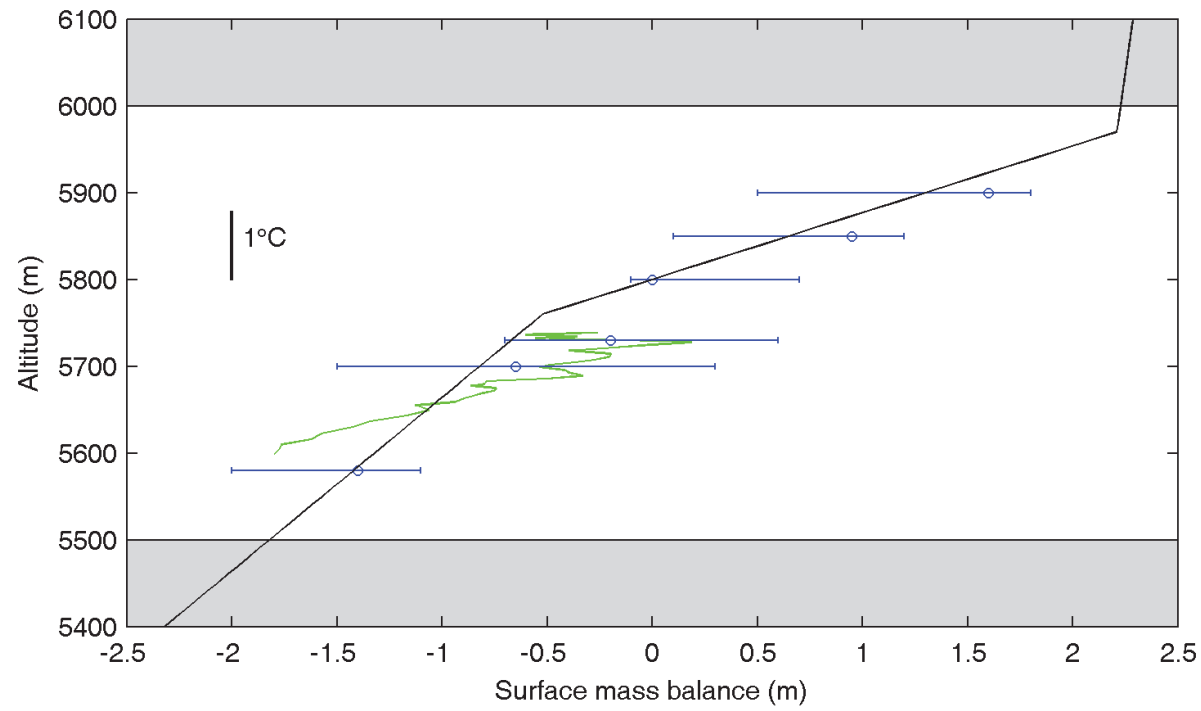

Fig. 3. Annual surface mass balance modeled by Eqs. (2) and (3) with ELA $=5800 \mathrm{~m}$ (black curve). The grey region corresponds to the altitude outside the altitude range of Gurenhekou glacier, which is $5500 \sim 6000 \mathrm{~m}$ a.s.l. The green curve is the rate of annual average surface change observed during the year $2007 \sim 2011$. The blue circles represent the median value of SMB from stake measurements (Yao et al., 2012), and the blue bar widths shows their variability. The vertical bar represents the change in ELA for a $1{ }^{\circ} \mathrm{C}$ change in summer temperature.

Numerical simulation of a Tibetan Plateau glacier

L. Zhao et al.

Title Page

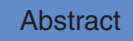

Introduction

Conclusions

References

Tables

Figures

14

4

Back

Full Screen / Esc

Printer-friendly Version

Interactive Discussion 


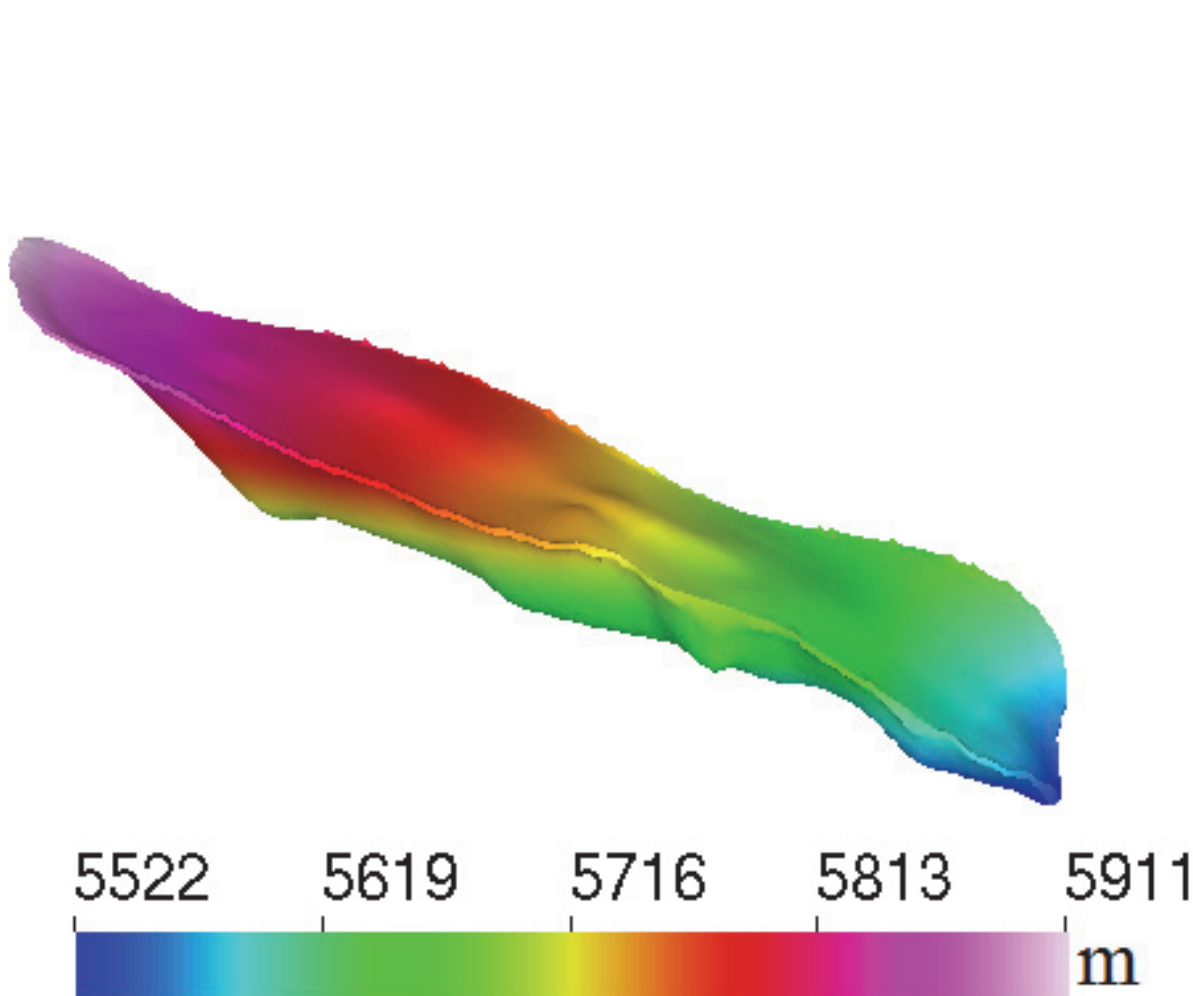

\section{Elevation}

Fig. 4. Three-dimensional representation of the glacier geometry created by DEM (the vertical coordinate is stretched by a factor of 3 ).

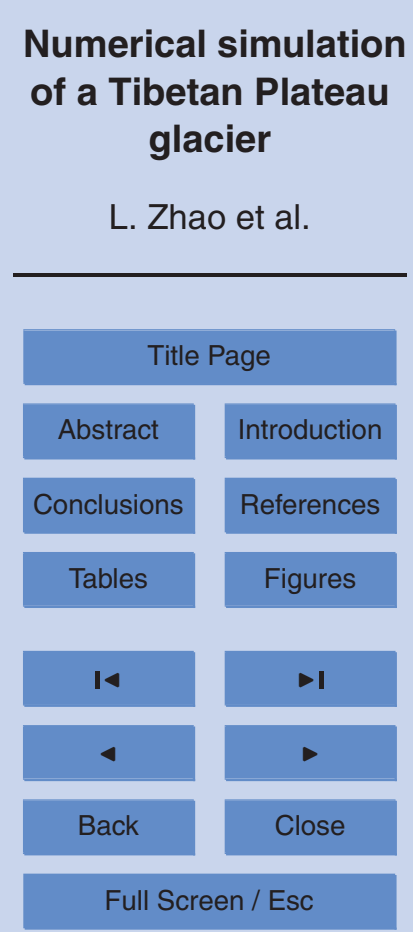

Printer-friendly Version

Interactive Discussion 


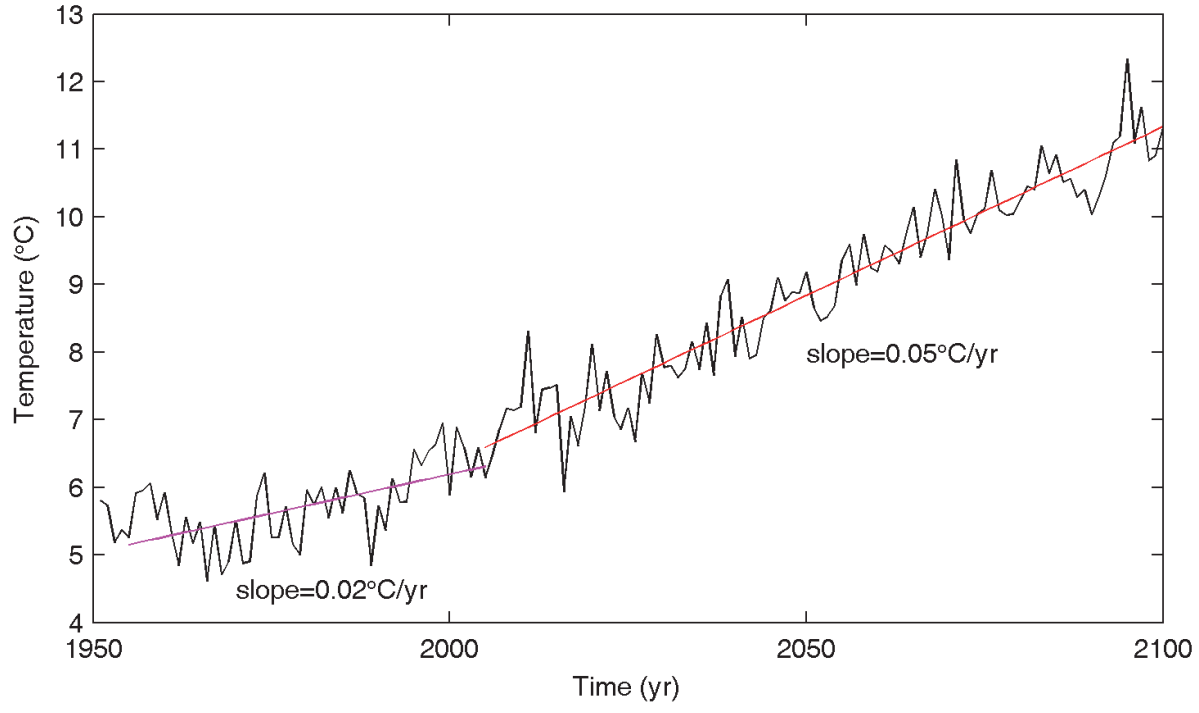

Fig. 5. JJA-mean air temperature from RegCM 3.0 simulations for mean temperatures of the 9 grid cells surrounding Gurenhekou glacier. The linear warming trends for the periods 1955 2005 and $2005 \sim 2100$ are drawn in magenta and red, respectively.
TCD

7, 145-173, 2013

Numerical simulation of a Tibetan Plateau glacier

L. Zhao et al.

Title Page

Abstract

Introduction

Conclusions

References

Tables

Figures

14

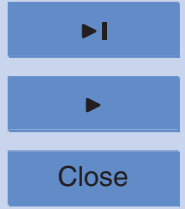

Back

Close

Full Screen / Esc

Printer-friendly Version

Interactive Discussion 


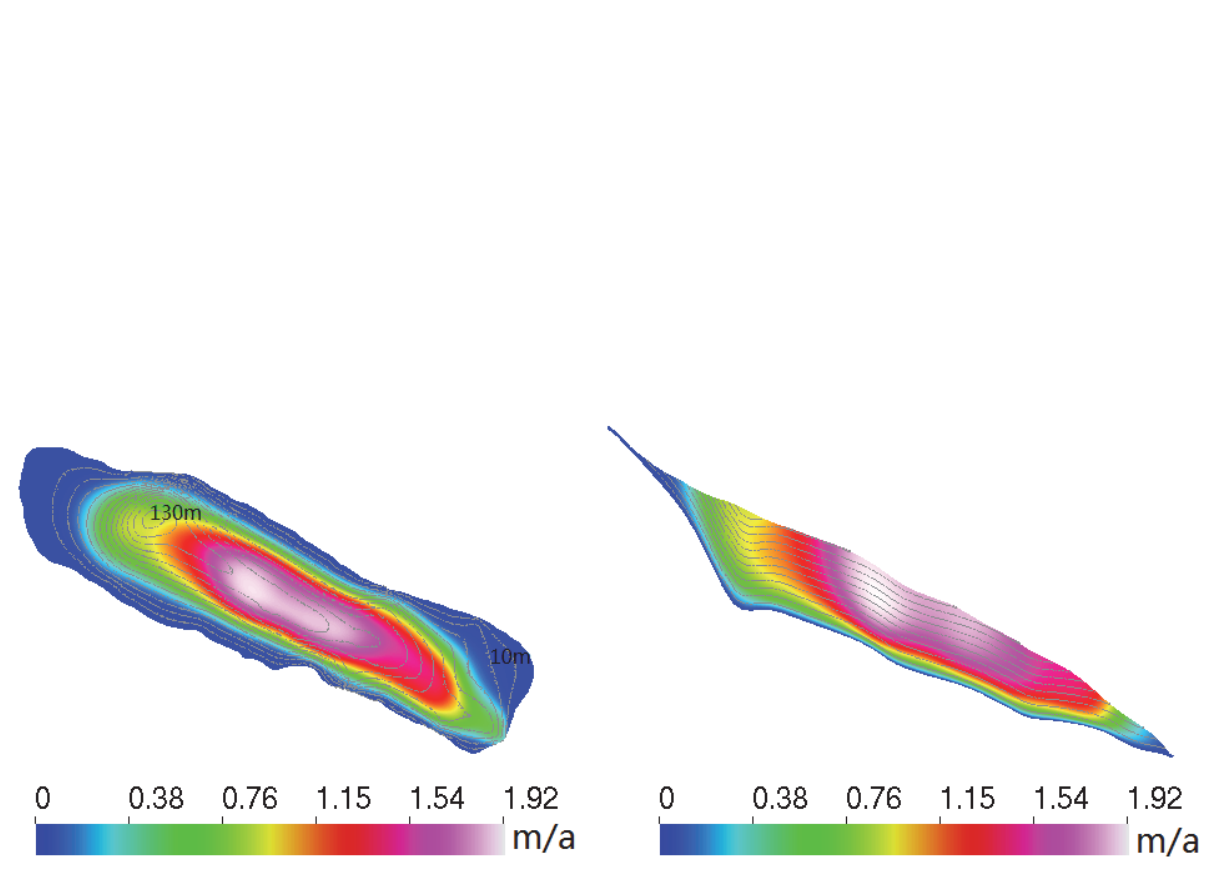

Fig. 6. The absolute value of ice flow velocity on the surface (left) and on the transect along the central line (right) of the diagnostic run (the vertical coordinate is stretched by 3 ). The contours indicate the ice thickness in $10 \mathrm{~m}$ interval from $10 \mathrm{~m}$ to $130 \mathrm{~m}$.

\section{Numerical simulation of a Tibetan Plateau glacier}

L. Zhao et al.

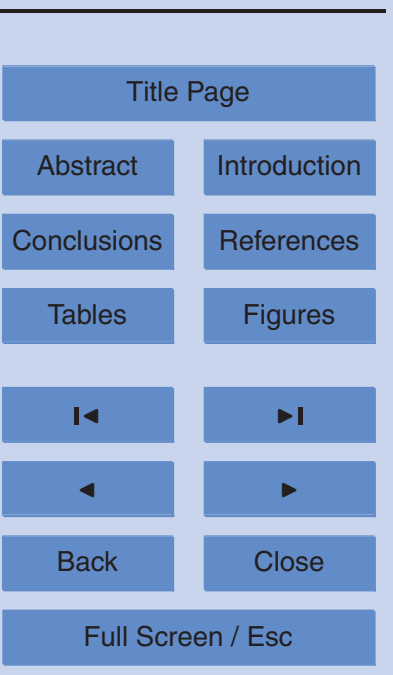

Printer-friendly Version

Interactive Discussion 


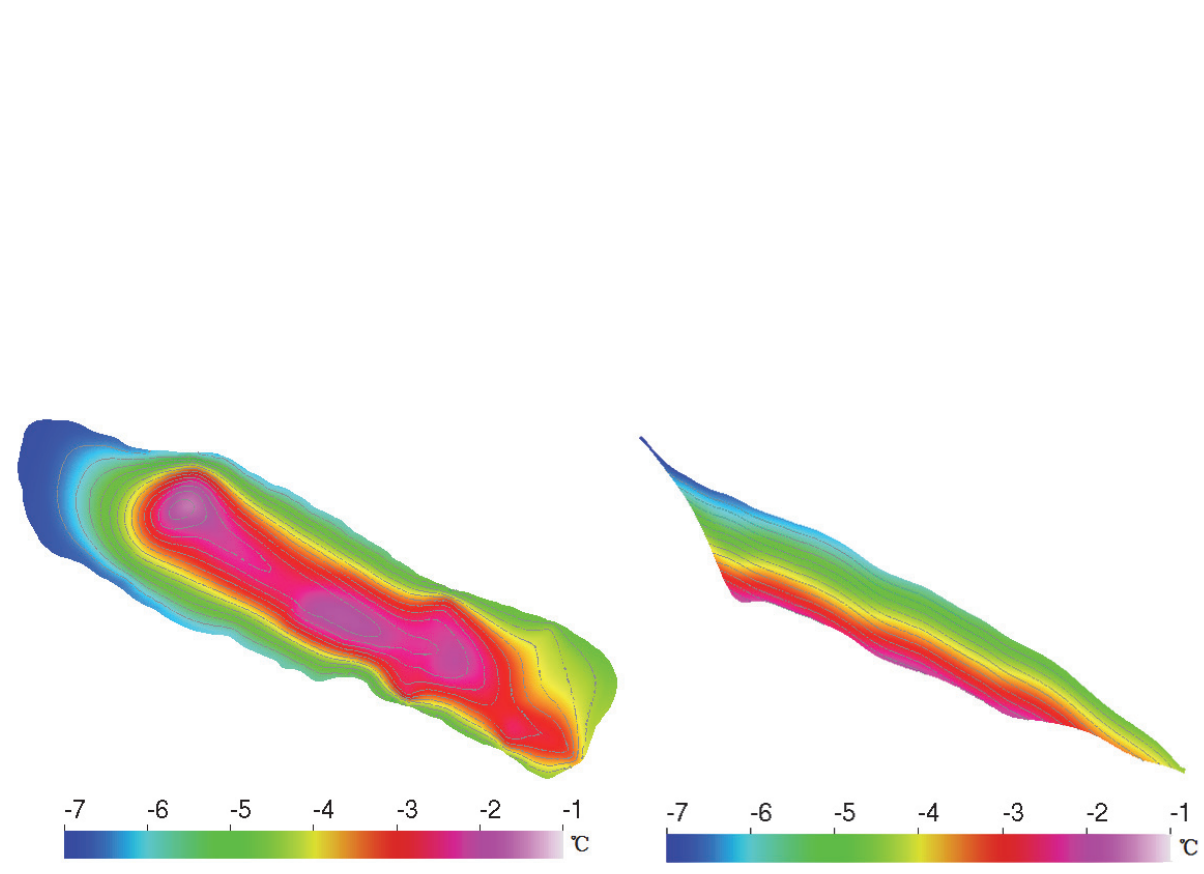

Fig. 7. Distribution of temperature relative to pressure melting point at the bedrock (left) and along the center line (right) of the diagnostic run (the vertical coordinate is stretched by 3 ). The contours indicate the ice thickness in $10 \mathrm{~m}$ interval from $10 \mathrm{~m}$ to $130 \mathrm{~m}$.

\section{TCD}

$7,145-173,2013$

\section{Numerical simulation of a Tibetan Plateau glacier}

L. Zhao et al.

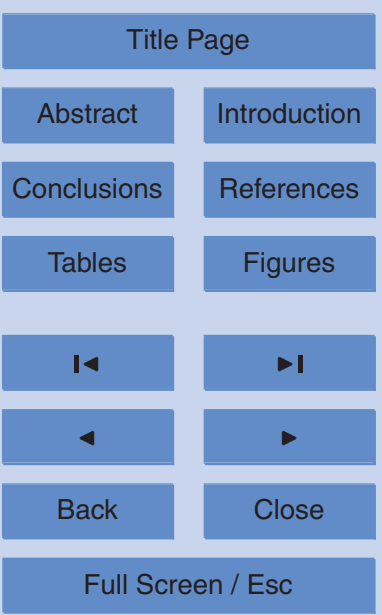

Printer-friendly Version

Interactive Discussion 


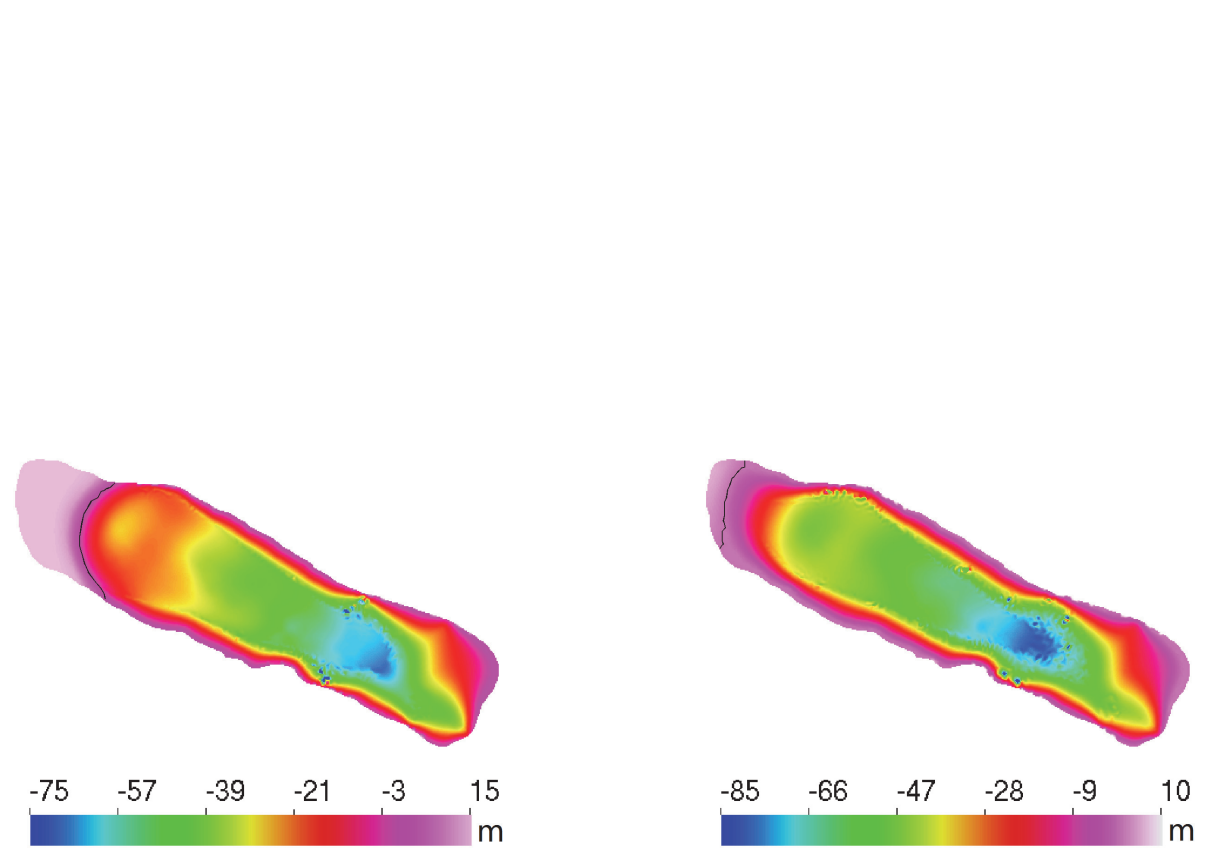

\section{TCD}

$7,145-173,2013$

Numerical simulation of a Tibetan Plateau glacier

L. Zhao et al.

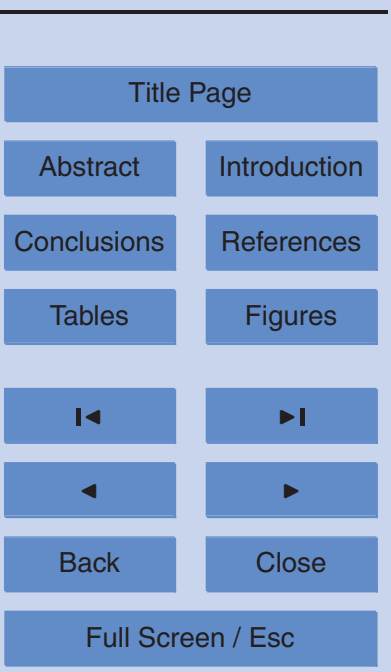

Printer-friendly Version

Fig. 8. Surface elevation change from 2008 to 2057 of prognostic simulations with $\dot{T}=0.02 \mathrm{Ka}^{-1}$ (left) and $\dot{T}=0.05 \mathrm{Ka}^{-1}$ (right). The black solid lines indicate zero net elevation change. 

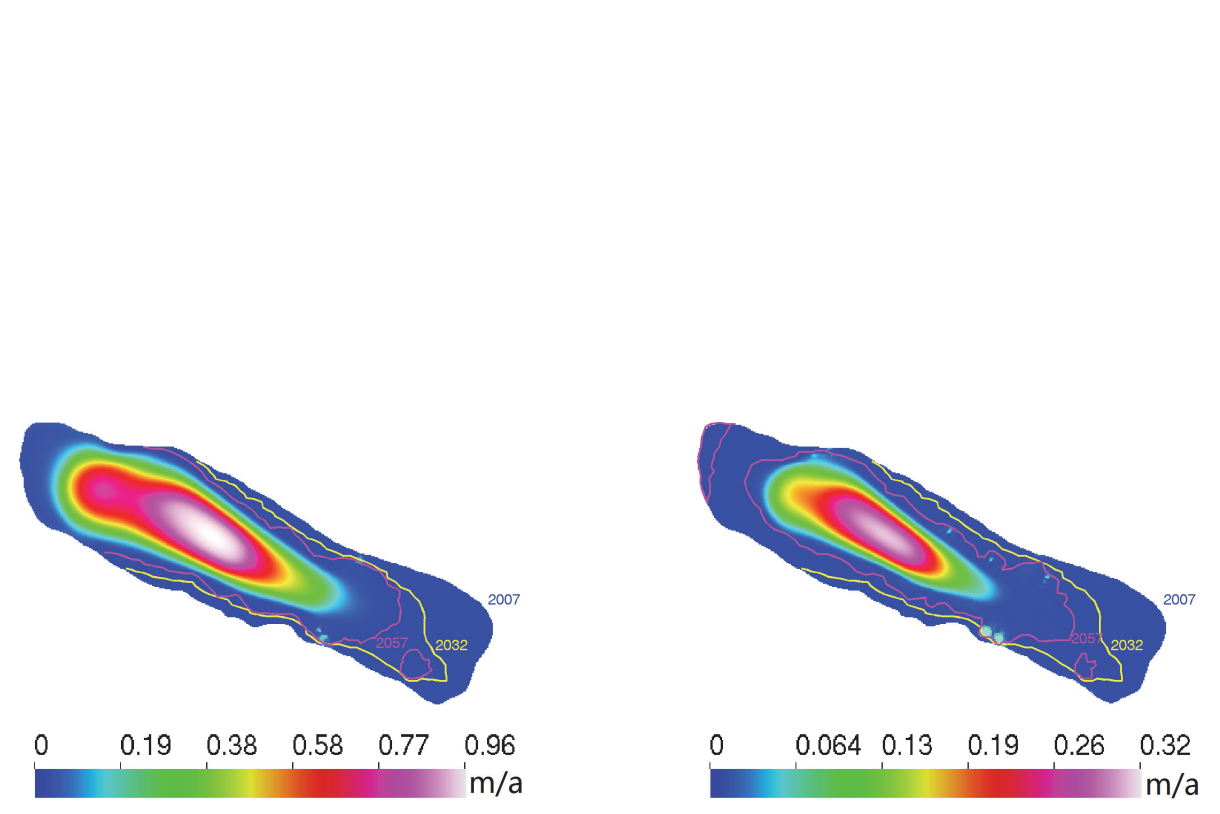

TCD

$7,145-173,2013$

\section{Numerical simulation of a Tibetan Plateau glacier}

L. Zhao et al.

Fig. 9. Result for surface flow velocity in the year 2057 of prognostic simulations with $\dot{T}=0.02 \mathrm{Ka}^{-1}$ (left) and $\dot{T}=0.05 \mathrm{Ka}^{-1}$ (right). The color bar shows the magnitude of velocity. The computed position of outlines in 2032 and 2057 are marked with solid lines in yellow and magenta, respectively.

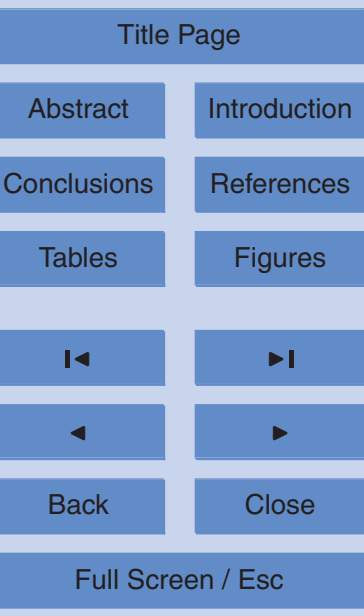

Printer-friendly Version

Interactive Discussion

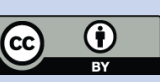




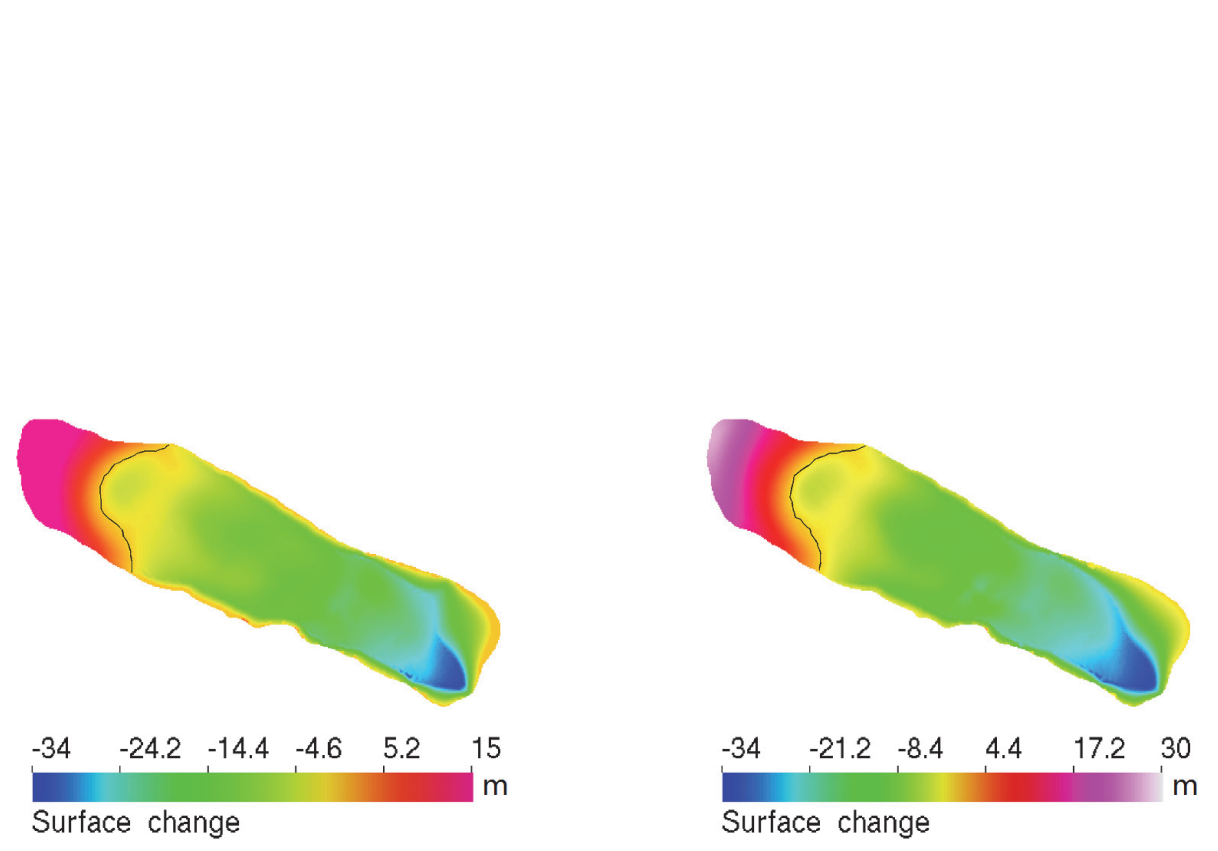

\section{TCD}

$7,145-173,2013$

\section{Numerical simulation of a Tibetan Plateau glacier}

L. Zhao et al.

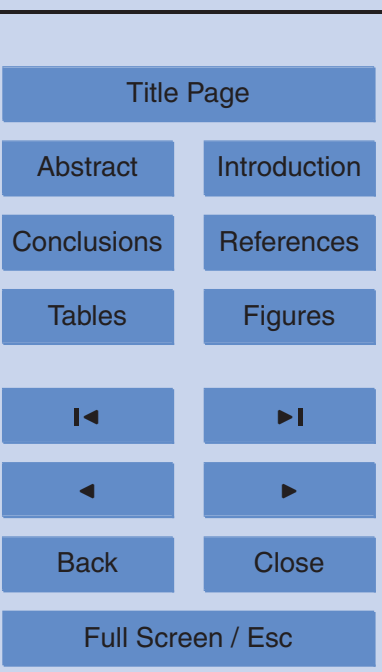

Printer-friendly Version

Fig. 10. Surface elevation change from 2008 to 2027 with surface increase restricted by $15 \mathrm{~m}$ (left) and unrestricted (right) from prognostic simulations using $\dot{T}=0.02 \mathrm{Ka}^{-1}$. The black solid lines indicate zero net elevation change. 